\title{
A Search for $O$-Polypeptidyl-Ribonucleic Acids in Rabbit-Reticulocyte Ribosomes by Electrophoresis in Phenol-Acetic Acid-Water Systems
}

\author{
BY INGER BRATTSTEN,* R. L. M. SYNGE AND W. B. WATT \\ The Rowett Research Institute, Bucksburn, Aberdeen
}

(Received 2 February 1965)

\begin{abstract}
1. When solutions of 'soluble' or transfer RNA (s-RNA) and of cytochrome $c$ in phenol-acetic acid-water were mixed, intractable coacervates were formed. The addition to the solutions of various strong electrolytes prevented coacervation and allowed electrophoretic separation on filter paper. Protein migrates cationically, leaving RNA at or near the origin. The separation is aided by adsorption of RNA to the paper. Special arrangements were necessary to prevent contamination of the paper by ultraviolet-absorbing electrode-reaction products. 2. Binding of alkali-metal cations to RNA and some other associations were observed in such solvent systems. Possible effects of ionic association on mobilities are discussed. 3. Rabbit-reticulocyte ribosomes were subjected to electrophoresis as above, after their nascent-protein moiety had been labelled with $\left[{ }^{14} \mathrm{C}\right]$ valine in the intact cell. Most of the radioactivity migrated with the ribosomal protein; such protein as remained near the origin with the RNA had valine of lower specific radioactivity. 4. Molecular-sieve chromatography in phenol-acetic acid-water indicated that the nascent-protein moiety was not of markedly lower molecular weight than the average for the ribosomal proteins. 5. These results are very tentatively taken to mean that the nascent-protein moiety of ribosomes so prepared is not $O$-polypeptidyl-s-RNA. It is postulated that, in the course of adding each amino acid residue, the growing polypeptide chain is transferred from ester linkage with s-RNA to linkage with ribosomal protein through its carboxyl group, perhaps by ester linkage to an alcoholic group. The two types of intermediate, $O$-polypeptidyl-s-RNA and polypeptidyl-protein, would be found in different proportions, depending on the isolation procedure used. Some implications and possible tests of this hypothesis are discussed.
\end{abstract}

Bishop, Leahy \& Schweet (1960) (cf. Nathans \& Lipmann, 1961 ; Lipmann, 1961) were the first to propose that, in the course of protein biosynthesis in ribosomes, the peptide chain is elongated by $O-N$ transfer of a polypeptidyl group, esterified on a terminal sugar residue of s-RNA, $\dagger$ to the free amino group of an amino acid residue itself esterified to another molecule of s-RNA. Judged by analogous reactions with smaller molecules (Porter, Rydon \& Schofield, 1960), this acyl migration could proceed at physiological $\mathrm{pH}$, without requiring extraneous free energy, and through a short-lived intermediate that would itself also be a large molecule (see Scheme 1).

The negative results of a search made in this Laboratory for low-molecular-weight intermediates of protein biosynthesis in leaves (Bagdasarian,

* Present address: Biochemical Institute, University of Gothenburg, Sweden.

† Abbreviation: s-RNA, 'soluble' or transfer RNA.
Matheson, Synge \& Youngson, 1964) seemed consistent with this hypothesis. In these experiments a mixture of phenol, acetic acid and water had been used, in the hope of ensuring extraction and of minimizing intermolecular interactions of the proteins, polypeptides etc., which were being studied. Previous electrophoretic experiments in the same solvent system (Synge, 1957; Bagdasarian, Matheson, Synge \& Youngson, 1962) had made it seem likely that $O$-polypeptidyl-s-RNA could be electrophoretically separated from protein, and perhaps also from RNA. Accordingly we undertook model experiments, of which a preliminary account has been published (Brattsten, Synge \& Watt, 1964), which suggested that such separations could best be realized by adding various strong electrolytes to the solvent system. Many further experiments are needed before the fundamental physical chemistry and the field of applicability of this technique will be understood. However, the 
$\mathrm{H}_{2} \mathrm{~N} \cdot \mathrm{CHR}_{(1)} \cdot \mathrm{CO} \cdots \mathrm{NH} \cdot \mathrm{CHR}_{(n)} \cdot \mathrm{CO}_{2} \cdot \mathrm{s}-\mathrm{RNA}_{(n)}+\mathrm{H}_{2} \mathrm{~N} \cdot \mathrm{CHR}_{(n+1)} \cdot \mathrm{CO}_{2} \cdot \mathrm{s}-\mathrm{RNA}_{(n+1)} \rightarrow$
$\mathrm{H}_{2} \mathrm{~N} \cdot \mathrm{CHR}_{(1)} \cdot \mathrm{CO} \cdots \mathrm{NH} \cdot \mathrm{CHR}_{(n)} \cdot \mathrm{C}^{\mathrm{O} \cdot \mathrm{O} \cdot \mathrm{s}-\mathrm{RNA}_{(n)}} \rightarrow$
$\mathrm{H}_{2} \mathrm{NH} \cdot \mathrm{CHR}_{(1)} \cdot \mathrm{CO} \cdot \mathrm{CHR}_{(n+1)} \cdot \mathrm{CO}_{2} \cdot \mathrm{s}-\mathrm{RNA}_{(n+1)}$$\rightarrow$

Scheme 1.

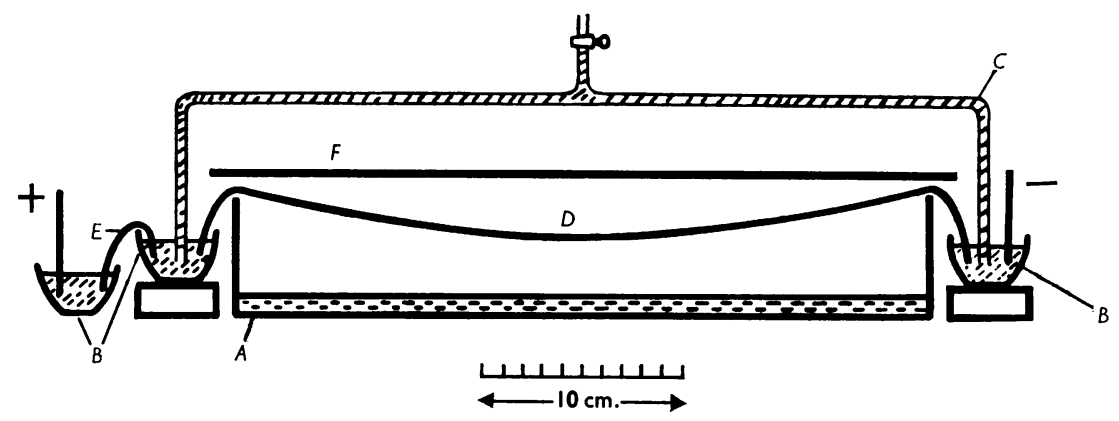

Fig. 1. Diagram of hanging-strip apparatus for filter-paper electrophoresis. $A$, Glass developing dish; $B$, glass troughs; $C$, levelling siphon; $D$, strip of filter paper; $E$, wicks made from several thicknesses of filter paper; $F$, glass plate (shown raised, but during run resting on paper to grip it against edge of dish); + and -, platinum-wire electrodes. During equilibration and running the apparatus was enclosed under a Perspex cover (not shown) resting on the bench.

results of our experiments on $\left[{ }^{14} \mathrm{C}\right]$ valine-labelled ribosomes from rabbit reticulocytes seem to have some relevance to current hypotheses about protein biosynthesis, and therefore to be worth publishing.

\section{MATERIALS}

Phenol-acetic acid-water mixtures were made from analytical-reagent phenol (distilled immediately before use) and analytical-reagent acetic acid. Solvent $I$ was $(1: 1: 1$, $w / v / v)$ and solvent II was $(2: 1: 1, w / v / v)$. Solvent IIA was a $1 \%(w / v)$ solution of cetylpyridinium bromide (British Drug Houses Ltd., Poole, Dorset) in solvent II, and solvent IIB was a $2 \%(w / v)$ solution of $\mathrm{NaBr}$ in solvent II.

Pelargonin chloride (preparation of Synge, 1944) was used as a cationic marker and $N$-DNP-ethanolamine as a neutral marker in filter-paper electrophoresis (Mould \& Synge, 1954). Cytochrome $c$ was bought from British Drug Houses Ltd. (no. 443970, biological origin not stated). Yeast RNA (presumably alkali-degraded) was also from British Drug Houses Ltd. 'Soluble' RNA (sodium salts) from fresh yeast (lot 62032) and from Escherichia coli (lot 63490) were bought from General Biochemicals Inc., Chagrin Falls, Ohio, U.S.A. The $\left[{ }^{14} \mathrm{C}\right]$ valine preparations used for labelling the ribosomes by Dr Morris and Dr Arnstein were all from The Radiochemical Centre, Amersham, Bucks.

\section{METHODS}

Filter-paper electrophoresis was done with the hangingstrip apparatus shown in Fig. 1 (developed by Bagdasarian et al. 1962) to avoid radioactive contamination of the apparatus. As low potential gradients were used (250 v was applied to the apparatus) and the solvent mixtures were not very volatile, this arrangement proved satisfactory. The starting line was at the bottom of the catenary formed by the paper. The intermediate trough siphoned into the anode trough through wicks consisting of several sheets of filter paper. The cathode trough was refilled from time to time, and liquid was removed from the anode trough. The stream of liquid towards the anode was needed to prevent non-volatile ultraviolet-absorbing electrode-reaction products from reaching the paper. For the electrophoreses, Whatman no. 1 filter paper was dipped in the solvent mixture, lightly blotted and mounted in the apparatus. The troughs and dish were filled with solvent mixture and the apparatus was left overnight without applied voltage to equilibrate. The specimen solutions or slurries were then applied to positions previously marked in pencil on the starting line and the field was switched on. At the end of the run the paper was removed, by clipping it to the glass plate, and dried hanging in its original orientation in a gentle current of warm air until the spaces between the fibres were free from liquid. It was then dried in an oven overnight at $105^{\circ}$, and washed in three changes of ethanol. Ultraviolet contact prints were made as described by 
Markham (1955), by using Ilford photographic paper (Contact C2.1P). Radioautographs (usual exposure about 9 weeks) were made as described by Synge \& Youngson (1961).

For quantitative study of the distribution of radioactivity on the papers, suitable areas were cut out and these, after further dissection, were placed in $0.3 \mathrm{~N}-\mathrm{KOH}$ (approx. $0.02 \mathrm{ml} . / \mathrm{cm} .{ }^{2}$ ) in a stoppered vessel for $17 \mathrm{hr}$. at $37^{\circ}$. A volume of $\mathrm{N}-\mathrm{HClO}_{4}$ equivalent to the $\mathrm{KOH}$ was then added, followed by a volume of phenol-acetic acid $(1: 1, w / v)$ twice the aggregate volume of $\mathrm{KOH}$ and $\mathrm{HClO}_{4}$ used. After occasional shaking for a few hours, the liquid above the paper was pipetted off and the paper further extracted with portions of solvent $I$. The combined extracts were evaporated in vacuo with repeated additions of water until phenol could no longer be smelt. The residue was hydrolysed by refluxing for $24 \mathrm{hr}$. in a mixture of $6 \mathrm{ml}$. of $10 \mathrm{~N}-\mathrm{HCl}$ and $4 \mathrm{ml}$. of acetic acid. After the hydrolysate had been evaporated to dryness, valine and its specific radioactivity were determined as by Bagdasarian et al. (1964). A blank determination on the paper well to the anode side of the starting line yielded $0.07 \mu \mathrm{g}$. of valine $/ \mathrm{cm}^{2}$ (devoid of detectable radioactivity) and this blank has been subtracted in recording the results.

RNA was determined in fractions from a control batch of unlabelled ribosomes by the procedure of Smillie \& Krotkov (1960), after removing phenol by evaporation in the presence of water and beginning the analysis at the KOH treatment. Typical nucleotide spectra were obtained in the eluates, and RNA was calculated from the extinction at $260 \mathrm{~m} \mu$, assuming $E_{1 \mathrm{~cm}}^{0.001 \%} 0 \cdot 3$.

Protein on the papers was stained after ultraviolet contact printing with Light Green (British Drug Houses Ltd.) $[0.5 \mathrm{~g} . / 100 \mathrm{ml}$. of acetic acid-ethanol-water $(1: 5: 14$, by vol.)] for $10 \mathrm{~min}$., washing being with aq. $2 \%(\mathrm{v} / \mathrm{v})$ acetic acid (Dangerfield \& Smith, 1955).

\section{RESULTS}

\section{Behaviour of model substances}

Cytochrome $c$ was used as a model protein in most of the experiments described below, since it is coloured and the haem group, being covalently linked to the protein, cannot migrate independently. Cytochrome $c$ and commercial yeast RNA (British Drug Houses Ltd.) yielded viscous liquid coacervates when their clear solutions in solvent $I$ were mixed (Bagdasarian et al. 1962; Brattsten et al. 1964). The RNA in solution in solvent $I$ was gradually degraded when the solution was kept; this was shown by progressive loss of power to give a coacervate with cytochrome $c$, less strong adsorption on filter paper during washing with aqueous solutions and the liberation of ultravioletabsorbing products (perhaps ribonucleoside $3^{\prime}, 5^{\prime}$ diphosphates) migrating towards the anode under our conditions of filter-paper electrophoresis. There were no signs of degradation of RNA during storage in phenol-acetic acid-water solutions when an equal or greater amount of protein was also present; presumably such solutions have both higher $\mathrm{pH}$ and higher buffering power. Fig. 2 shows the behaviour on filter-paper electrophoresis in solvent I of cytochrome $c$ and commercial (alkali-degraded) yeast RNA alone and in mixture (experiment of Bagdasarian et al. 1962). The mixture was applied as supernatant plus coacervate, and some of the interaction must have been due to the presence of two phases in the early stages of the separation.

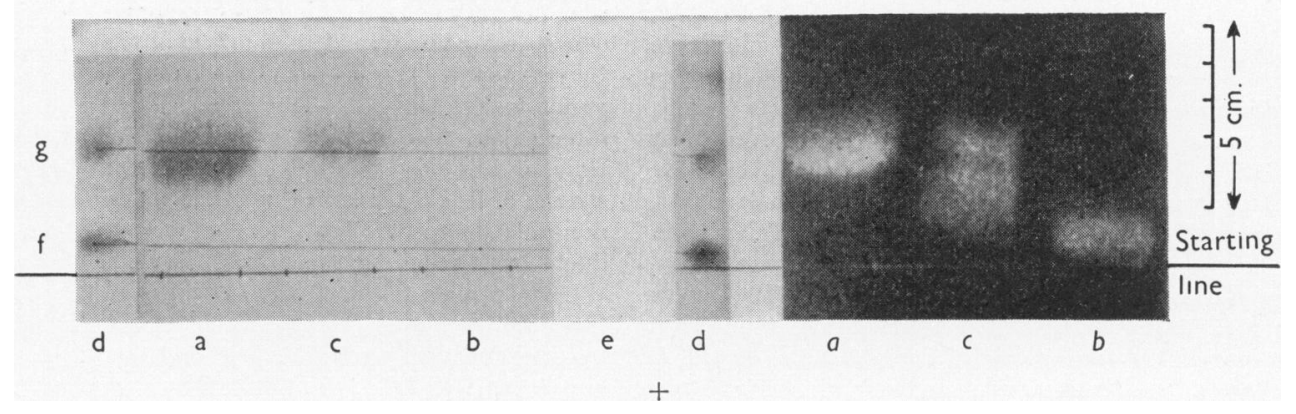

Fig. 2. Electrophoresis in phenol-acetic acid-water $(1: 1: 1, w / v / v)$ (solvent $I$ ) for $7 \mathrm{hr}$. a-d show original filter paper; $a-c$ an ultraviolet print of part thereof. After making the ultraviolet print, the marker strips were cut off the edge of the paper, and a-c were stained with Light Green before photography. Strip e carried a sample irrelevant to the present work and has been masked out. Solutions applied to starting line: $a, a, 0.5 \%$ cytochrome $c$; b, $b, 0.5 \%$ yeast RNA (degraded); c, $c, 0.5 \%$ cytochrome $c+0.5 \%$ yeast RNA (degraded); d, marker pigments, $N$-DNP-ethanolamine (f)+pelargonin chloride (g). Movement of $N$-DNP-ethanolamine was due to uneven siphoning of liquid along the paper, not to electroendosmosis. The electrophoretic migrations should therefore be referred to the pencil lines joining the marker spots. 
However, we observed some interaction in experiments with mixtures in which the RNA was so degraded that coacervation did not occur.

Yeast or $\boldsymbol{E}$. coli s-RNA could, at least partially, be dissolved in solvent $I$, but, on mixing such solutions with solutions of an equal weight of cytochrome $c$ in solvent $I$, nearly all the cytochrome $c$ was precipitated with the nucleic acid as a very hard coacervate that was obviously useless for electrophoretic separations. With solvent II somewhat softer, but still useless, coacervates resulted.

Ribosomal extracts made with solvent I contained more than $90 \%$ of the ribosomal protein and $15-25 \%$ of the ribosomal RNA (see below). On filter-paper electrophoresis in solvent $I$ they gave

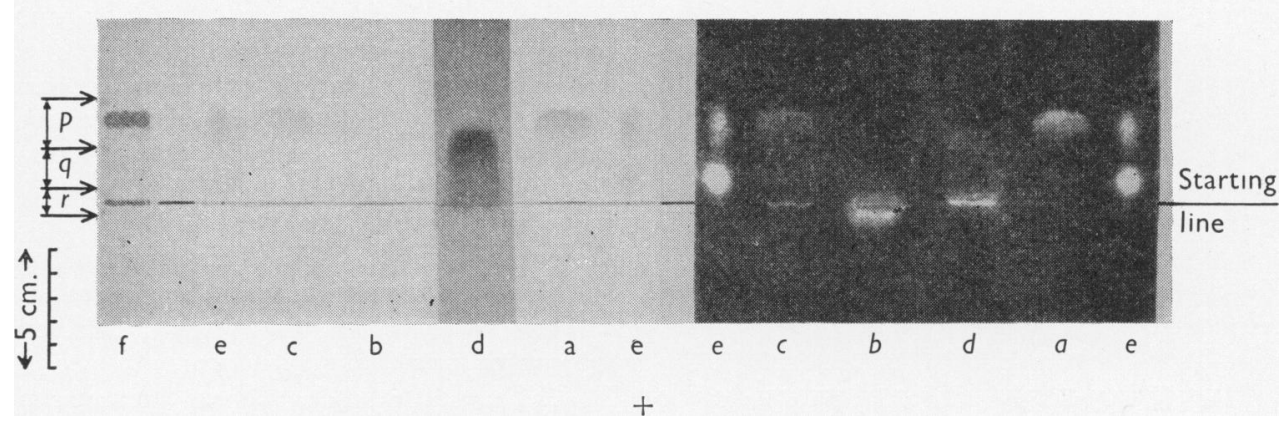

Fig. 3. Electrophoresis in phenol-acetic acid-water $(2: 1: 1, w / v / v)$ containing $1 \%(w / v)$ of cetylpyridinium bromide (solvent IIA) for $22 \frac{1}{2} \mathrm{hr}$. a-e show original filter paper; $a-e$, an ultraviolet print thereof. After making the ultraviolet print, $d$ was cut out of the paper and stained with Light Green before photographing. Samples applied to starting line: a, $a, 100 \mu \mathrm{g}$. of cytochrome $c ; \mathrm{b}, b, 100 \mu \mathrm{g}$. of yeast s-RNA; c, $c, 100 \mu \mathrm{g}$. of cytochrome $c+100 \mu \mathrm{g}$. of yeast s-RNA; $d, d, 450 \mu \mathrm{g}$. of dry matter extractable with solvent I from unlabelled Morris ribosomes (see the text and Table 2); e, e, 30 $\mu \mathrm{g}$. of pelargonin chloride $+30 \mu \mathrm{g}$. of $N$-DNP-ethanolamine; $\mathrm{f}$ is a composite sketch of distribution of blackening in radioautograms of electrophoreses of labelled ribosomal material, shortened horizontally and reduced in scale vertically to correspond roughly with the shorter running time. To the left of this are shown the cuts made after radioautography (Table 2).

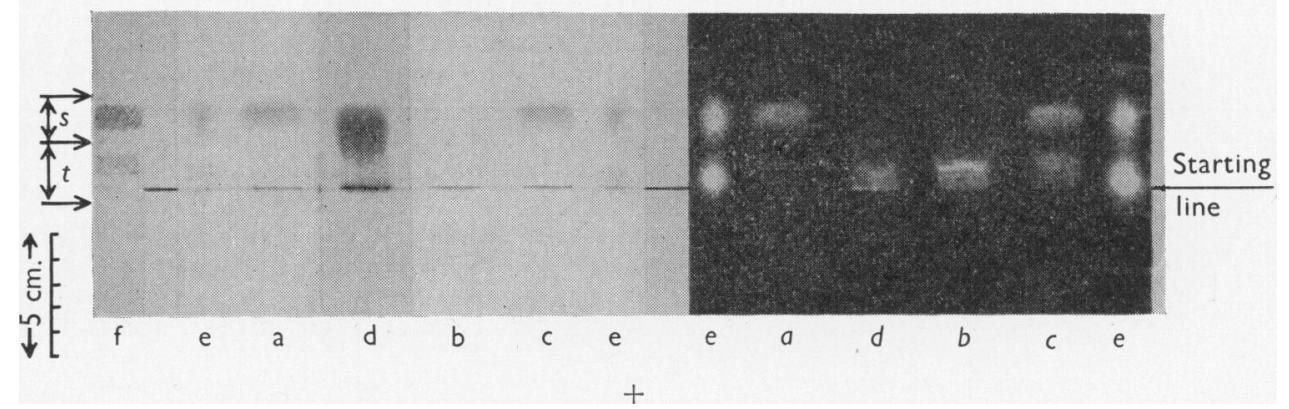

Fig. 4. Electrophoresis in phenol-acetic acid-water $(2: 1: 1, w / v / v)$ containing $2 \%(w / v)$ of $\mathrm{NaBr}$ (solvent IIB) for $46 \frac{1}{2} \mathrm{hr}$. a-e show original filter paper; $a-e$, an ultraviolet print thereof. After making the print, $d$ was cut out of the paper and stained with Light Green before photographing. Samples applied to starting line: a, $a, 100 \mu \mathrm{g}$. of cytochrome $c ; \mathrm{b}, b, 100 \mu \mathrm{g}$. of $E$. coli s-RNA; c, $c, 100 \mu \mathrm{g}$. of cytochrome $c+100 \mu \mathrm{g}$. of $E$. coli s-RNA; d, $d$, $450 \mu \mathrm{g}$. of dry matter extractable with solvent I from unlabelled Morris ribosomes (see the text and Table 2); $\mathrm{e}, e, 20 \mu \mathrm{g}$. of pelargonin chloride $+20 \mu \mathrm{g}$. of $N$-DNP-ethanolamine; $\mathrm{f}$ is a composite sketch of distribution of blackening in radioautograms of electrophoreses of ribosomal material, shortened horizontally and reduced in scale vertically to correspond roughly with the shorter running time. To the left of this are shown the cuts made after radioautography (Table 2 ). 
very diffuse cationically migrating zones, in which there was little resolution of RNA from protein, although the RNA appeared to be concentrated in the more slowly migrating part of the zone.

We found that cetylpyridinium bromide prevents the coacervation of s-RNA with cytochrome $c$ in solvent II. Later, we found that several simple inorganic salts are just as effective. We have studied in most detail the solutions of cetylpyridinium bromide (solvent IIA) and of sodium bromide (solvent IIB), and more cursorily solutions of other alkali-metal halides and of sodium toluene$p$-sulphonate in solvent II.

On electrophoresis in such solutions on filter paper, cytochrome $c$ and s-RNA behaved in mixtures much as when separate, with little sign of interaction at any stage of the run, whether judged by visible or ultraviolet light. Figs. 3 and 4 show their behaviour in solvents IIA and IIB respectively.

The behaviour of the N-DNP-ethanolamine used as marker for electroendosmosis is of some interest. In solvent I or solvent IIB it did not move. In solvent IIA it invariably migrated towards the cathode, as shown in Fig. 3. However, we are not inclined to interpret this movement as due to electroendosmosis, since the effect of adsorption of cetylpyridinium ions by the paper would be to cause electroendosmosis towards the anode. Indeed, aqueous pyridine-acetic acid buffers reverse the usual cationic electroendosmosis in paper into electroendosmosis towards the anode. It is more reasonable to suppose that $N$-DNP-ethanolamine takes part in some kind of cationic complex with cetylpyridinium ions. Under these circumstances it is not clear whether RNA is carried towards the anode by eleatroendosmosis or by ionic migration.

Assuming that there is no electroendosmosis in the paper, it seems that RNA bears little net charge in the solvent systems studied. In solvent I, degraded RNA, when free from protein, migrates slightly towards the cathode. In solvent IIA, migration of s-RNA is towards the anode, though considerably limited by adsorption on the paper, especially when protein is present. In solvent IIB, migration is definitely cationic, as it is also in solvent II containing $1.5 \%(\mathrm{w} / \mathrm{v})$ of sodium toluene- $p$ sulphonate or made $0.2 \mathrm{M}$ with respect to potassium bromide, lithium bromide, sodium chloride, potessium chloride or lithium chloride.

The migration of RNA on the paper must be to some extent decreased by adsorption, since filterpaper chromatograms developed with the same solvent mixtures showed considerable streaking of RNA, all of which did not, like cytochrome $c$, migrate with the velocity of the solvent mixture $\left(R_{,} 1\right)$. In solvent IIB, s-RNA migrated notably more slowly than the British Drug Houses Ltd. (degraded) yeast RNA. This could afford opportunities for chromatographic fractionations.

The conductivities, viscosities and electrophoretic migration rates for cytochrome $c$ are shown in Table 1 for some of the solvent mixtures used.

\section{Experiments with $\left[{ }^{14} \mathrm{C}\right]$ valine-labelled reticulocyte ribosomes}

Ribosomal preparations were subjected to filter-paper electrophoresis in solvent IIA for $48 \mathrm{hr}$. or solvent IIB for $96 \mathrm{hr}$.; after radioautography, the selected areas were cut out, extracted and hydrolysed, and the specific radioactivity of the valine was determined. Figs. 3 and 4 show the general distribution of ultraviolet absorption, protein staining (Light Green) and radioactivity resulting from such electrophoreses. They also show the location of the cuts made.

Ribosomes prepared by ultracentrifugation in

Table 1. Some physical properties of the solvent mixtures used

\begin{tabular}{|c|c|c|c|}
\hline Solvent mixture & $\begin{array}{c}\text { Conductivity } \\
\text { at } 20^{\circ} \\
(\text { mhocm. } \\
-1)\end{array}$ & $\begin{array}{c}\text { Viscosity } \\
\text { at } 20^{\circ} \\
\text { (centipoises) }\end{array}$ & $\begin{array}{l}\text { Whatman no. } 1 \\
\text { paper soaked in } \\
\text { solvent mixture } \\
\left(\mathrm{cm}^{2} \mathrm{v}^{-1} \text { sec. }{ }^{-1}\right)\end{array}$ \\
\hline Solvent I [phenol-acetic acid-water $(1: 1: 1, w / v / v)]$ & $0 \cdot 000170$ & $3 \cdot 03$ & $2.9 \times 10^{-5 *}$ \\
\hline Solvent II [phenol-acetic acid-water $(2: 1: 1, \mathrm{w} / \mathrm{v} / \mathrm{v})]$ & 0.000059 & $\mathbf{3 \cdot 6 2}$ & - \\
\hline $\begin{array}{l}\text { Solvent IIA [phenol-acetic acid-water }(2: 1: 1, w / v / v) \\
\text { containing } 1 \%(w / v) \text { of cetylpyridinium bromide] }\end{array}$ & $0 \cdot 000453$ & $3 \cdot 75$ & $1.5 \times 10^{-5} \dagger$ \\
\hline $\begin{array}{l}\text { Solvent IIB }[\mathrm{phenol-acetic} \mathrm{acid-water}(2: 1: 1, w / v / v) \\
\text { containing } 2 \%(w / v) \text { of } \mathrm{NaBr}]\end{array}$ & 0.00281 & 3.95 & $0.7 \times 10^{-5} \dagger$ \\
\hline
\end{tabular}

Migration rate for cytochrome $c$ on Whatman no. 1 paper soaked in solvent mixture

mhocm. ${ }^{-1}$ ) tipoises)

Solvent I [phenol-acetic acid-water $(1: 1: 1, w / v / v)]$ Solvent II [phenol-acetic acid-water $(2: 1: 1, \mathrm{w} / \mathrm{v} / \mathrm{v})$ ] Solvent IIA [phenol-acetic acid-water $(2: 1: 1, w / v / v)$ Solvent IIB [phenol-acetic acid-water $(2: 1: 1, \mathrm{w} / \mathrm{v} / \mathrm{v})$ * Value of Synge (1957). of experiments. 
potassium hydrogen carbonate medium. These were prepared for us by Dr A. J. Morris at the National Institute for Medical Research, Mill Hill, London. Whole cells were incubated with amino acid mixture in which only valine was radioactive $(0.16 \mathrm{mM}$ DL-[carboxy- $\left.{ }^{14} \mathrm{C}\right]$ valine, $4 \cdot 76 \mu \mathrm{c} / \mu$ mole) and worked up as described by Morris (1964). The resulting ribosomal pellets (wet wt. $110 \mathrm{mg}$.) were triturated with 5 parts (by wt.) of phenol-acetic acid-water $(2: 2: 1, w / v / v)$ before being brought to Aberdeen, where the preparation was stored at $0-2^{\circ}$ over 6-12 months. The product consisted of a bulky flocculent precipitate in a clear supernatant. The supernatant was decanted and replaced with five changes of solvent I. Table 2 shows that the final precipitate contained $86 \%$ of the RNA and $8.4 \%$ of the ribosomal valine; thus $14 \%$ of the RNA and $91.6 \%$ of the valine had proved extractable. All results in Tables 2 and 3 relate to the original pellets. Measured portions (approx. one-tenth) of the pooled extracts were evaporated to small volume in vacuo below $37^{\circ}$ with repeated additions of aq. $1 \%(\mathrm{v} / \mathrm{v})$ acetic acid (to maintain acid reaction), adjusted in composition to that of the electrophoretic medium and applied, along with any material that had become insoluble, to an approx. $10 \mathrm{~cm}$. length of starting line. Filter-paper electrophoresis was carried out in solvents IIA and IIB. The results are given in Table 2.

Another portion of the pooled supernatants was

Table 2. Distribution of valine and radioactivity in fractions derived from $\left[{ }^{14} \mathrm{C}\right]$ valine-labelled ribosomes by extraction and electrophoresis for phenol-acetic acid-water systems

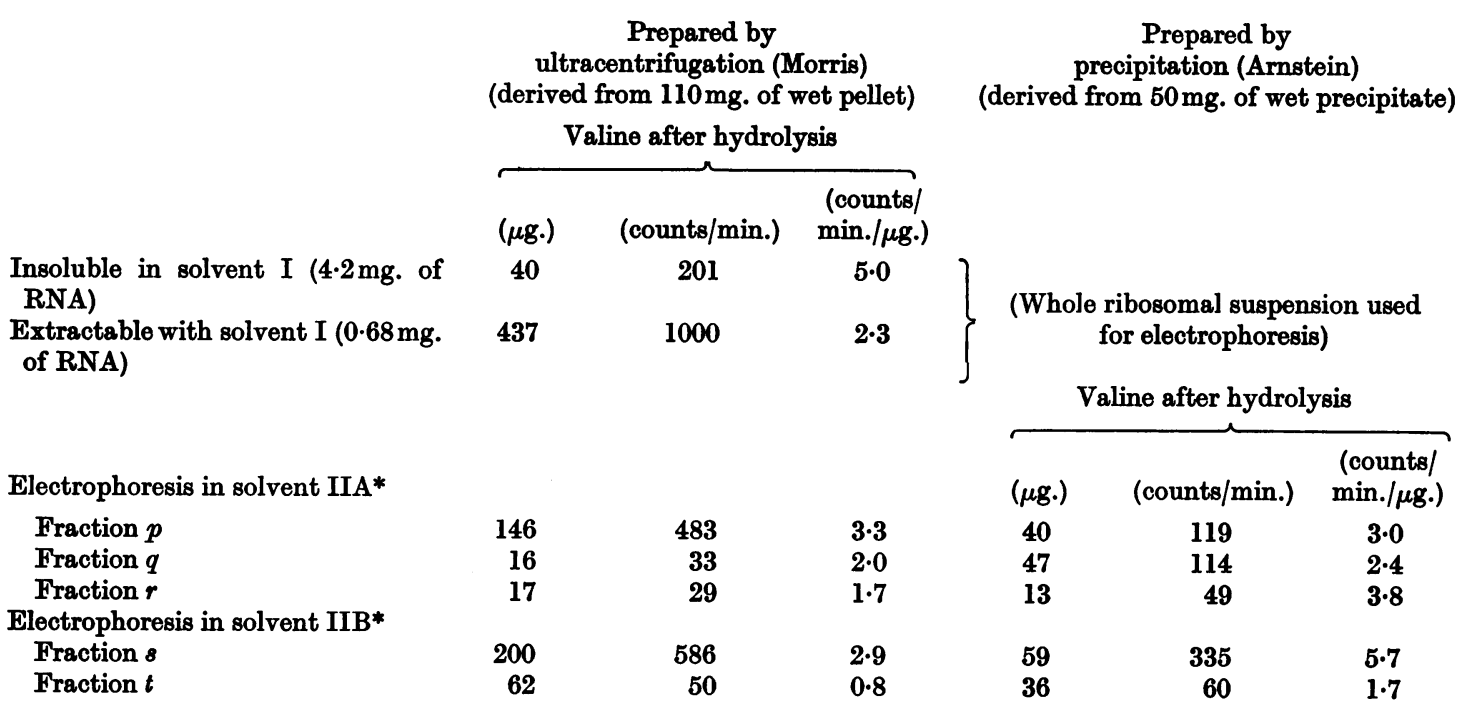

* Only the fraction extractable into solvent I of the Morris ribosomes was subjected to electrophoresis.

Table 3. Distribution of valine and radioactivity in fractions derived from $\left[{ }^{14} \mathrm{C}\right]$ valine-labelled ribosomes by chromatography on Sephadex G-75 in phenol-acetic acid-water $(1: 1: 1, w / v / v)$ (solvent I)

\begin{tabular}{|c|c|c|}
\hline \multicolumn{3}{|c|}{$\begin{array}{c}\text { From } 110 \mathrm{mg} \text {. of wet pellet prepared by } \\
\text { ultracentrifugation (Morris) }\end{array}$} \\
\hline$(\mu \mathrm{g})$. & (counts/min.) & (counts/min./ $/ \mu \mathrm{g}$. ) \\
\hline 437 & 1000 & $2 \cdot 3$ \\
\hline 410 & 950 & $2 \cdot 3$ \\
\hline 10 & 38 & $3 \cdot 8$ \\
\hline $9 \dagger$ & 4 & 0.4 \\
\hline
\end{tabular}

In extract taken for chromatography

Fraction $a^{*}$

Fraction $b^{*}$

Fraction $c^{*}$

* See the text, and also Bagdasarian et al. (1964).

$\uparrow$ No free valine or radioactivity of free valine could be detected in this fraction. 
fractionated by chromatography in solvent $I$ on Sephadex G-75 into fractions $a, b$ and $c$, supposedly of high, medium and low molecular weight (Bagdasarian et al. 1964). There was no detectable radioactivity present as free valine in fraction $c$. The distribution of valine and its radioactivity after evaporation of the fractions and acid hydrolysis is shown in Table 3.

Ribosomes prepared by precipitation at $\mathrm{pH} 6$ (Cox \& Arnstein, 1964; Arnstein, Cox, Gould \& Potter, 1965). These were prepared for us by $\mathrm{Dr}$ H. R. V. Arnstein, of the National Institute for Medical Research, Mill Hill, London, from reticulocytes labelled by incubation of whole cells (21ml.) at $37^{\circ}$ for $5 \mathrm{~min}$. in Tyrode solution $(32 \mathrm{ml}$.) and a solution $\left(6.5 \mathrm{ml}\right.$.) of $\left[{ }^{14} \mathrm{C}\right]$ valine $(6.5 \mu$ moles of DL-[4-14C] valine, 9.8 $\mu \mathrm{C}$, plus $0 \cdot 6 \mu$ mole of $\mathrm{L}$-[U-14C]valine, $15 \mu \mathrm{C}$ ) containing also all protein amino acids (2 $\mu \mathrm{moles} / \mathrm{ml}$.) except valine.

After cooling to $0^{\circ}$, reticulocytes were isolated from $42.5 \mathrm{ml}$. of incubation mixture by centrifuging $(500 \mathrm{~g}$ for $10 \mathrm{~min}$.$) , washed twice with ice-cold$ $0 \cdot 145 \mathrm{~m}$-sodium chloride and lysed as described by Schweet, Lamfrom \& Allen (1958). Cell debris was removed by centrifuging at $11500 \mathrm{~g}$ for $10 \mathrm{~min}$., and ribosomes were isolated by adjusting the $\mathrm{pH}$ of the supernatant to 6 with $\mathrm{N}$-acetic acid and centrifuging at $11500 \mathrm{~g}$ for $10 \mathrm{~min}$. The sedimented ribosomes were dissolved in $9 \mathrm{ml}$. of medium $A_{1}$ (0.25 M-sucrose-25 mM-potassium chloride-1 mMmagnesium chloride-50 mM-tris-hydrochloric acid buffer, pH 7.6) (Arnstein, Cox \& Hunt, 1964) and reprecipitated at $\mathrm{pH} 6$ as before.

Each final ribosomal precipitate obtained by the above procedure from $5 \mathrm{ml}$. of packed red cells (approx. 50 mg. wet wt.) was made up to $2.0 \mathrm{ml}$. in solvent IIA or solvent IIB. Most of the material went into solution, but there was insoluble flocculent material. Portions $(0.3 \mathrm{ml}$.) of these slurries were taken, evaporated to small volume with repeated additions of aq. $1 \%$ acetic acid as above and subjected to filter-paper electrophoresis in solvents IIA and IIB respectively as before. The same appearances resulted and corresponding cuts and analyses were made, the results of which are shown in Table 2. The electrophoreses were completed within a month of the preparation of the ribosomes.

Table 2 shows that the valine remaining with the RNA insoluble in solvent I had about twice the specific radioactivity of that extractable into solvent I. However, $83 \%$ of the total radioactivity (and thus of the nascent-peptide chains) was extractable into solvent I. Apart from the small fraction $r$ from the ribosomes prepared by $D r$ Arnstein, the valine in those fractions migrating with or closest to RNA ( $q, r$ and $t$ ) had lower specific radioactivity than in the fractions ( $p$ and $s$ ) migrating with protein.
Table 3 shows that, under conditions that should have isolated peptides of mol.wt. less than 3000 in fractions $b$ and $c, 95 \%$ of the nascent-peptide chains extractable into solvent I remained with the bulk of the ribosomal proteins in fraction $a$. The specific radioactivity of the valine in fraction $b$ (mol.wt. 1000-3000) was not greatly enhanced, whereas that in fraction $c$ (mol.wt. less than 1000) was diminished.

\section{DISCUSSION}

Physical chemistry of the separations. The object of the present work was to devise an electrophoretic system in which there should be clear separation of protein and RNA; in such a system $O$-polypeptidyls-RNA might be expected to exhibit an intermediate behaviour.

There have been numerous, though sporadic, studies of the electrophoretic separation of proteins and nucleic acids in aqueous buffers. In many such studies no separation was observed, and in others separations were imperfect, and gave evidence of the existence of more or less stable protein-nucleic acid complexes. It was hoped that separation could be improved by the use of dissociating solvent mixtures, and early experiments with phenolacetic acid-water $(1: 1: 1, \mathrm{w} / \mathrm{v} / \mathrm{v})$, in which a degraded commercial yeast RNA was used (Fig. 2; cf. Bagdasarian et al. 1962), gave some encouragement. However, with less-degraded RNA specimens intractable coacervates resulted, and such RNA as remained in the supernatant phase migrated in close association with the protein. We were encouraged to try to prevent this coacervation and association in our solvent mixtures as a result of a discussion with Professor R. M. Barrer on the dispersal of clay minerals in organic solvents (cf. Barrer, 1962) and by the work of Ebel and colleagues (for references see Stahl \& Ebel, 1964 ; Weil, Hebding \& Ebel, 1963) on the properties of quaternary ammonium salts of nucleic acids. We found that cetylpyridinium bromide prevents the coacervation of s-RNA with cytochrome $c$ in phenol-acetic acid-water $(2: 1: 1$, $\mathrm{w} / \mathrm{v} / \mathrm{v}$ ). Later, we found that several simple inorganic uni-univalent salts are just as effective in preventing coacervation. The salts permit independent electrophoretic migration of our model substances, cytochrome $c$ and s-RNA. Even in aqueous buffers, the interaction of oppositely charged polyelectrolytes is decreased by raising the ionic strength, and the effect is likely to be greater in a medium of relatively low dielectric constant. It is reasonable, in fact, to picture the univalent ions as forming ion pairs (Bjerrum theory) with oppositely charged groups in the polyelectrolytes. Such a picture seems necessary to explain the cationic migration of s-RNA in the solutions containing alkali-metal cations. Similar binding of 
cations by long-chain polyphosphates has been studied in detail by U. P. Strauss and colleagues (for references see Strauss \& Siegel, 1963). Ross \& Scruggs (1964) have studied the binding of cations by DNA in electrophoresis. In both studies, it was found that $\mathrm{Na}^{+}$etc. were more firmly bound than $\mathrm{N}\left(\mathrm{CH}_{3}\right)_{4}{ }^{+}$. This is in accord with our present observations on the relative directions of migration of s-RNA in the presence of sodium bromide and cetylpyridinium bromide respectively.

The apparent association of $N$-DNP-ethanolamine with cetylpyridinium ions is likewise of interest. The physical explanation of this, and of other interactions that we have observed during electrophoresis of leaf extracts in such systems, requires further detailed experiments.

Adsorption on the paper of nucleic acids manifestly plays a part in the separations achieved, and should be favourable to them, since the more slowly migrating components are also those most retarded by adsorption.

The cationic mobilities of proteins in phenolacetic acid-water are not directly proportional to their content of basic amino acid residues (Synge, 1957; and Fig. 5). They are also much lower than would be exhibited by the same proteins in a state of maximum cationic charge in aqueous solution. Here again, the most reasonable explanation seems to be formation of ion pairs between the charged groups of the proteins and acetate counter-ions. The closer together such groups are located in the polyelectrolyte, the greater will be the extent of

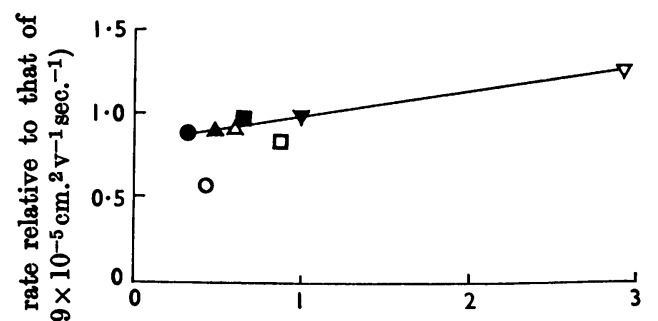

Content of $(\mathrm{Arg}+\mathrm{His}+\mathrm{Lys}+\mathrm{Orn})$ relative to that of cytochrome $c$ (mol.prop.)

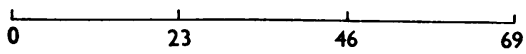

Content of (Arg + His + Lys + Orn) residues as \% of total residues

Fig. 5. Cationic migration rates of proteins and polypeptides on filter paper in phenol-acetic acid-water ( $1: 1: 1$, $\mathrm{w} / \mathrm{v} / \mathrm{v}$ ) (solvent I) (results of Synge, 1957) plotted against. content of basic amino acid residues. $\bullet$, Insulin; $O$, tyrocidine; $\Delta$, papain; $\Delta$, ribonuclease; $\square$, lysozyme; $\square$, gramicidin $S ; \nabla$, cytochrome $c ; \nabla$, salmine. their neutralization by counter-ions, and this effect will be further promoted by a medium of low dielectric constant. Table 1 shows how the addition of strong electrolytes still further lowers the mobility of cytochrome $c$.

Ribosomes contain proteins of a wide variety of charge types (Waller, 1963, 1964). However, in the light of these observations with model proteins, we would not expect ribosomal proteins to migrate in our solvent systems at rates very different from one another, and in fact the bulk of the ribosomal protein migrates on filter paper as a not very broad zone somewhat slower than cytochrome c. The striking electrophoretic separations of ribosomal proteins in similar solvent mixtures in polyacrylamide gel, reported by Work (1964), are therefore presumably due to retarding effects of the gel structure.

In the present experiments a substantial proportion of the ribosomal protein was held by the nucleic acid either in an insoluble state or secondarily adsorbed on the paper; the separation of ribosomal protein from ribosomal RNA was by no means as complete as that of cytochrome $c$ from s-RNA. It might be expected that the ribosomal proteins richest in basic amino acids would be most tenaciously held by the RNA, but we have no evidence bearing on this question. Wallace, Squires \& Ts'o (1961) isolated a basic ribosomalprotein fraction, also of low specific activity.

The longest nascent-peptide chains expected to be found attached to s-RNA in globin biosynthesis do not exceed the s-RNA in molecular weight. If the peptide moiety of such polypeptidyl-s-RNA molecules has the cationic mobility of a typical protein and the RNA moiety little ionic mobility, such polypeptidyl-s-RNA molecules would have about half the cationic mobility of a protein. Those with shorter peptide chains would have lower mobilities. One would further expect the migration of all polypeptidyl-s-RNA species to be decreased by adsorption on the paper mediated by their RNA moiety. It is therefore reasonable to conclude that any $O$-polypeptidyl-s-RNA present would migrate, in our systems, either with or slightly to the cathode side of the main RNA zone, and would thus be isolated in the RNA-rich fractions eluted from the papers $(q, r$ and $t)$. We have not excluded the possibility that some s-RNA, including polypeptidyl-s-RNA, may have been carried with the protein further towards the cathode. The results of Work (1964) with 32P-labelled ribosomes make this seem unlikely.

Stability of O-polypeptidyl-s-RNA. Rigorous deductions from our results are made impossible because we have not had available for control experiments $O$-polypeptidyl-s-RNA authenticated by synthesis or otherwise. The material could 
therefore, by virtue of some instability, be lost during our isolation procedure. Simon, Littauer \& Katchalski (1964) have synthesized poly- $\beta$-benzylL-aspartyl, polylysyl and poly-S-methylmethionyl derivatives of s-RNA, but these would have a charge distribution in the peptide moiety very different from that in growing peptide chains of haemoglobin. We have therefore to rely on circumstantial evidence of stability :

(i) Peptide bonds in the polypeptide moiety are likely to be stable under our conditions. Bagdasarian et al. (1964) made a detailed study of this question, using leaf proteins, and found no sign of scission of peptide bonds.

(ii) Internucleotide bonds in the RNA moiety are probably stable as long as excess of protein is present (see above under 'Behaviour of model substances') but slowly hydrolysed in its absence, on account of the lower $\mathrm{pH}$ of the solution. Such degradation is probably too slow to affect the behaviour of $O$-polypeptidyl-s-RNA under the conditions of our separations. Our main evidence for this is from the adsorption experiments described above; s-RNA was more strongly adsorbed on paper from our solvent mixtures than was commercial (degraded) yeast RNA, and s-RNA that had been in solution for several days still showed this stronger adsorption.

(iii) The carboxylic ester bond would be expected to be less subject to hydrolysis or rearrangement in weakly acid solution than under neutral or alkaline conditions. $O$-Aminoacyl-s-RNA molecules have long been known to be stable at pH 2-3 (e.g. Hoagland, Stephenson, Scott, Hecht \& Zamecnik, 1958). The biosynthetic $O$-polylysyl-s-RNA of Rychlik (1964), the postulated structure of which is supported by the work of Bretscher (1963), is stable to trichloroacetic acid and perchloric acid. The ester bond in these compounds would be somewhat stabilized to acid hydrolysis by the proximity of $-\mathrm{NH}_{3}{ }^{+}$groups. Nevertheless, it is reasonable to expect stability of the ester bond, in the $O$-polypeptidyl-s-RNA with which we are concerned, to the considerably weaker acetic acid.

For these reasons we expect that $O$-polypeptidyls-RNA, if present in the ribosome preparations, would be stable during our extraction and electrophoretic procedures. Our subsequent alkaline treatment of the paper was designed to break both ester and internucleotide bonds, and thus make easier the extraction from the paper of peptide material with phenol-acetic acid-water, which for peptides is both a good solvent and a powerful displacing agent from the adsorbed state.

Implications for protein biosynthesis. We appreciate the difficulty of establishing the negative conclusion that highly radioactive $O$-polypeptidyls-RNA is absent from our preparations; this requires model experiments with authentic $O$. polypeptidyl-s-RNA material when this becomes available. On the other hand, the simplest conclusion from our experiments and arguments is that most of the nascent-peptide chains are chemically linked to protein-like rather than to RNA-like larger molecules. They show no sign, on molecularsieve chromatography, of being present as free peptides (cf. Bagdasarian et al. 1964; Carnegie, 1965). These conclusions also emerge from the results of Wallace et al. (1961) and of Gazzinelli \& Dickman (1964) (see also Dintzis, Borsook \& Vinograd, 1958).

The results of Bretscher (1963) and of Arlinghaus, Shaeffer \& Schweet (1964) seem, on the other hand, conclusive for the occurrence of $O$-polypeptidyls-RNA molecules as intermediates. Other work purporting to show the same is less easy to assess, because both types of intermediate might be expected to show: (i) similar behaviour in the ultracentrifuge or on Sephadex, since proteins often have molecular weights in the same range as those of s-RNA; (ii) similar lability to alkali, hydroxylamine etc., since the carboxyl group of the nascentpeptide chain could in each case be linked to the large molecule by ester-type linkage. Other questions of technique may also complicate interpretation (McQuillen, 1961; Takanami, 1962, 1964; Allen, 1963; Ehrenstein, 1963; Gilbert, 1963; Slapikoff, Fessenden \& Moldave, 1963; Schlessinger \& Gros, 1964 ; Elson, 1963 ; Gierer, $1964 a, b$; Rychlik, 1964; Bresler, Vasil'eva, Graevskaya, Kirillov \& Saminskiǐ, 1964).

These apparently conflicting results can be reconciled by supposing that the stage catalysed by the TF-1 enzyme preparation in the scheme of Arlinghaus et al. (1964) (cf. Traut \& Monro, 1964) consists, not merely of the binding of a molecule of $O$-aminoacyl-s-RNA to the ribosome, but also of the transfer, mediated by GTP, of the growing peptide chain from $O$-peptidyl-s-RNA to some state of 'high-energy' linkage to one or other of the ribosomal proteins. For simplicity, ester linkage to the primary alcoholic group of a serine residue may be postulated. The reaction scheme would be as shown in eqns. (1)-(6) (Scheme 2). The products of reaction (6) would be ready to react with one another as in reaction (2), and so on.

If we assume the intermediate forms (I) and (III) to be relatively short-lived, the growing peptide chain would alternate between the state of esterification to protein (II) and to s-RNA (IV). Which intermediate was isolated could then depend more on the manner in which the ribosomes were incubated and isolated than on the relative durations of these states of linkage. Hawtrey (1964) has postulated somewhat similar ortho-compounds as intermediates. 
$\mathrm{H}_{2} \mathrm{~N} \cdot \mathrm{CHR}_{(1)} \cdot \mathrm{CO}_{2} \cdot \mathrm{s}-\mathrm{RNA}_{(1)} \stackrel{\mathrm{TF}-1}{\longrightarrow}\left(\mathrm{H}_{2} \mathrm{~N} \cdot \mathrm{CHR}_{(1)} \cdot \mathrm{CO}_{2} \cdot \mathrm{s}-\mathrm{RNA}_{(1)}\right)$

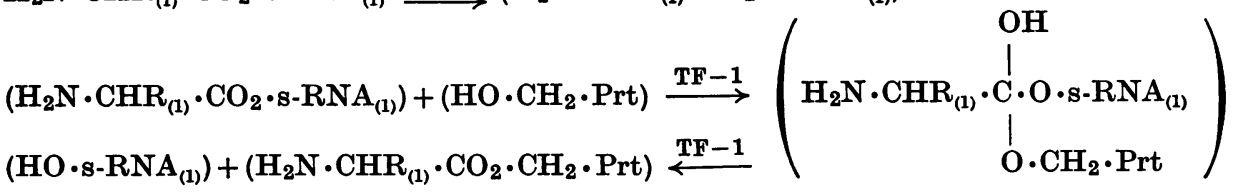

(I)

$$
\begin{aligned}
& \left.\left(\mathrm{HO} \cdot \mathrm{s}-\mathrm{RNA}_{(1)}\right)+\mathrm{H}_{2} \mathrm{~N} \cdot \mathrm{CHR}_{(2)} \cdot \mathrm{CO}_{2} \cdot \mathrm{s}-\mathrm{RNA}_{(2)} \stackrel{\mathrm{TF}-1}{\longrightarrow} \mathrm{H}_{2} \mathrm{~N} \cdot \mathrm{CHR}_{(2)} \cdot \mathrm{CO}_{2} \cdot \mathrm{s}-\mathrm{RNA}_{(2)}\right)+\mathrm{HO} \cdot \mathrm{s}-\mathrm{RNA}_{(1)} \\
& \left(\mathrm{H}_{2} \mathrm{~N} \cdot \mathrm{CHR}_{(2)} \cdot \mathrm{CO}_{2} \cdot \mathrm{s}-\mathrm{RNA}_{(2)}\right) \\
& +\left(\mathrm{H}_{2} \mathrm{~N} \cdot \mathrm{CHR}_{(1)} \cdot \mathrm{CO}_{2} \cdot \mathrm{CH}_{2} \cdot \mathrm{Prt}\right) \\
& \begin{array}{r}
\left(\mathrm{H}_{2} \mathrm{~N} \cdot \mathrm{CHR}_{(1)} \cdot \mathrm{CO} \cdot \mathrm{NH} \cdot \mathrm{CHR}_{(2)} \cdot \mathrm{CO}_{2} \cdot \mathrm{s}-\mathrm{RNA}(2)\right) \\
+\left(\mathrm{HO} \cdot \mathrm{CH}_{2} \cdot \mathrm{Prt}\right)
\end{array} \\
& \stackrel{\mathrm{TF}-2}{\longrightarrow}\left(\begin{array}{c}
\mathrm{H}_{2} \mathrm{~N} \cdot \mathrm{CHR}_{(1)} \cdot \mathrm{C} \cdot \mathrm{OH} \cdot \mathrm{CH}_{2} \cdot \mathrm{Prt} \\
\mathrm{NH}_{\mathrm{NH}} \cdot \mathrm{CHR}_{(2)} \cdot \mathrm{CO}_{2} \cdot \mathrm{s}-\mathrm{RNA}_{(2)}
\end{array}\right)
\end{aligned}
$$

Scheme 2. $\left(\mathrm{HO} \cdot \mathrm{CH}_{2} \cdot \mathrm{Prt}\right)$ signifies the ribosomal protein in question; substances in parentheses are considered to be bound to the ribosome.

Direct treatment of living cells with phenolacetic acid mixtures might well stabilize both $O$-polypeptidyl-s-RNA species and polypeptidylproteins and permit an assessment of the proportions in which they occur under physiological conditions. They could probably be separated by electrophoresis as described above. O-Polypeptidyls-RNA species would be found contaminated with much $O$-aminoacyl-s-RNA species, but their relative proportions could easily be assessed after saponification.

The best test of our hypothesis would be isoletion, from among the ribosomal proteins, of the component or components carrying the nascentpeptide chains, i.e. of a protein fraction having much-enhanced specific radioactivity. Wallace et al. (1961) and Gazzinelli \& Dickman (1964) have made a good start in this direction. The methods that we have used here are unsuitable because they do not separate the various ribosomal proteins. The procedure of Work (1964) seems promising, and he tells us that he is doing experiments along these lines.

We thank Dr H. R. V. Arnstein, Professor R. M. Barrer, Dr E. I. McDougall, Dr P. Meares and Dr T. S. Work for useful discussions, Dr Arnstein and Dr. A. J. Morris for the preparations of labelled ribosomes, Mr D. J. Benzie for the radioautography, and $\mathrm{Mr}$ W. M. Laird, Mr H. G. Mitchell and Mr A. H. Ritchie for skilful help with the experiments.

\section{REFERENCES}

Allen, D. W. (1963). Biochim. biophys. Acta, 68, 418.

Arlinghaus, R., Shaeffer, J. \& Schweet, R. (1964). Proc. nat. Acad. Sci., Wash., 51, 1291.
Arnstein, H. R. V., Cox, R. A., Gould, H. \& Potter, H. (1965). Biochem.J. 96, 500.

Arnstein, H. R. V., Cox, R. A. \& Hunt, J. A. (1964). Biochem.J. 92, 648.

Bagdasarian, M., Matheson, N. A., Synge, R. L. M. \& Youngson, M. A. (1962). Biochem. J. 84, 103 P.

Bagdasarian, M., Matheson, N. A., Synge, R. L. M. \& Youngson, M. A. (1964). Biochem. J. 91, 91.

Barrer, R. M. (1962). Chem. \& Ind. p. 1258.

Bishop, J., Leahy, J. \& Schweet, R. (1960). Proc. nat. Acad. Sci., Wash., 46, 1030.

Brattsten, I., Synge, R. L. M. \& Watt, W. B. (1964). Biochem. J. 92, 1 P.

Bresler, S. E., Vasil'eva, N. N., Graevskaya, R. A., Kirillov, S. V. \& Saminskil, E. M. (1964). Biokhimiya, $29,353$.

Bretscher, M. S. (1963). J. molec. Biol. 7, 446.

Carnegie, P. R. (1965). Biochem. J. 95, 9 P.

Cox, R. A. \& Arnstein, H. R. V. (1964). Biochem.J. 93, 33 c. Dangerfield, W. G. \& Smith, E. B. (1955). J. clin. Path. $8,132$.

Dintzis, H. M., Borsook, H. \& Vinograd, J. (1958). In Microsomal Particles and Protein Synthesis, p. 95. Ed. by Roberts, R. B. London: Pergamon Press Ltd.

Ehrenstein, G. von (1963). In Informational Macromolecules, p. 419. Ed. by Vogel, H. J., Bryson, V. \& Lampen, J. O. New York: Academic Press Inc.

Elson, D. (1964). Biochim. biophys. Acta, 80, 379.

Gazzinelli, G. \& Dickman, S. R. (1964). Arch. Biochem. Biophys. 105, 641.

Gierer, A. (1964a). Abstr. 6th int. Congr. Biochem., New York, I-S16.

Gierer, A. (1964b). In New Perspectives in Biology, p. 106. Ed. by Sela, M. Amsterdam: Elsevier Publishing Co. Gilbert, W. (1963). J. molec. Biol. 6, 389.

Hawtrey, A. O. (1964). Nature, Lond., 202, 1179.

Hoagland, M. B., Stephenson, M. L., Scott, J. F., Hecht, L. I. \& Zamecnik, P. C. (1958). J. biol. Chem. 231, 241.

Lipmann, F. (1961). Proc. 5th int. Congr. Biochem., Moscow, vol. 1, p. 121. 
McQuillen, K. (1961). In Protein Biosynthesis, p. 263. Ed. by Harris, R. J. C. London: Academic Press (Inc.) Ltd.

Markham, R. (1955). In Moderne Methoden der Pflanzenanalyse, vol. 4, p. 246. Ed. by Paech, K. \& Tracey, M. V. Berlin: Springer-Verlag.

Morris, A. J. (1964). Biochem. J. 91, 611.

Mould, D. L. \& Synge, R. L. M. (1954). Biochem. J. 58, 585.

Nathans, D. \& Lipmann, F. (1961). Proc. nat. Acad. Sci., Wash., 47, 497.

Porter, G. R., Rydon, H. N. \& Schofield, J. A. (1960). J. chem. Soc. p. 2686.

Ross, P. D. \& Scruggs, R. L. (1964). Biopolymers, 2, 79.

Rychlik, I. (1964). Abstr. 6th int. Congr. Biochem., New York, I-171.

Schlessinger, D. \& Gros, F. (1963). J. molec. Biol. 7, 350.

Schweet, R. S., Lamfrom, H. \& Allen, E. H. (1958). Proc. nat. Acad. Sci., Wash., 44, 1029.

Simon, S., Littauer, U. Z. \& Katchalski, E. (1964). Biochim. biophys. Acta, 80, 169.
Slapikoff, S., Fessenden, J. M. \& Moldave, K. (1963). J. biol. Chem. 238, 3670.

Smillie, R. M. \& Krotkov, G. (1960). Canad. J. Bot. 38, 31. Stahl, A. J. C. \& Ebel, J.-P. (1964). Bull. Soc. Chim. biol., Paris, 46, 395.

Strauss, U. P. \& Siegel, A. (1963). J. phys. Chem. 67, 2683. Synge, R. L. M. (1944). Biochem. J. 38, 65.

Synge, R. L. M. (1957). Biochem. J. 65, 266.

Synge, R. L. M. \& Youngson, M. A. (1961). Biochem. J. 78, 708.

Takanami, M. (1962). Biochim. biophys. Acta, 61, 432.

Takanami, M. (1964). Proc. nat. Acad.Sci., Wash., 52, 1271.

Traut, R. R. \& Monro, R. E. (1964). J. molec. Biol. 10, 63.

Wallace, J. M., Squires, R. F. \& Ts'o, P. O. P. (1961). Biochim. biophys. Acta, 49, 130.

Waller, J.-P. (1963). J. molec. Biol. 7, 483.

Waller, J.-P. (1964). J. molec. Biol. 10, 319.

Weil, J.-H., Hebding, N. \& Ebel, J.-P. (1963). Bull. Soc. Chim. biol., Paris, 45, 595.

Work, T. S. (1964). J. molec. Biol. 10, 544. 